\title{
KAJIAN KARAKTERISTIK DAN POLA PENGGUNAAN LAHAN WILAYAH KEPESISIRAN PURWOREJO
}

\author{
Gaby Nanda Kharisma', Rizky Adriadi Ghiffari², Surono3, Zulfitrani Busrah4, Zulhan \\ Effendy ${ }^{5}$, Nurul Khakim 6 \\ 1Universitas Sembilanbelas November Kolaka \\ ${ }^{2} \mathrm{CV}$ Kreasi Hunian Rakyat \\ ${ }^{3}$ LKP Geospasial Buminusantara \\ 4Dinas Pertanian Kabupaten Bantaeng \\ ${ }^{5}$ Direktorat Topografi Angkatan Darat TNI AD \\ ${ }^{6}$ Departemen Sains Informasi Geografi, Fakultas Geografi, Universitas Gadjah Mada. \\ Email corresponding: gabykharisma@usn.ac.id
}

\begin{abstract}
Purworejo is a regency on the southern coast of Java has a potential resource but due to the aspect of disaster risk, this regency is also classified in the disaster risk assessment index class starting from the low, middle and high classes. The research objective is to examine the physical characteristics and land use patterns of coastal areas in Purworejo Regency, Central Java to then determine the coastal area strategy in the area. The location of the study is Munggangsari Beach, Grabag District, Purworejo Regency, Central Java Province. The methods used in this study include literature studies, remote sensing, field surveys (observation and measurement), and interviews. From the results of data and image analysis, there was an increase in livestock and pond fisheries activities in the Purworejo Coastal area from 2006 to 2014. The existence of these activities has the potential to harm the surrounding environment, one of which is groundwater quality. Whereas land use in the form of vacant and physical land generally decreases in area. This shows that from 2006 - 2016 there was high population pressure. Policy, technical capacity (early warning system procurement) is needed for the institution and strong emergency response mechanism in its application.
\end{abstract}

Keywords: Purworejo, Coastal Region, Disaster risk, Remote Sensing, Early Warning System

\begin{abstract}
Abstrak
Purworejo sebagai kabupaten yang berada di wilayah kepesisiran selatan Pulau Jawa memiliki potensi sumberdaya tetapi bila ditinjau dari aspek risiko bencana kabupaten ini juga terkasifikasi pada kelas indeks kajian risiko bencana mulai dari kelas rendah, menengah, dan tinggi. Tujuan penelitian untuk mengkaji karakteristik fisik dan pola penggunaan lahan wilayah kepesisiran Kabupaten Purworejo, Jawa Tengah untuk kemudian menentukan strategi wilayah kepesisiran pada daerah tersebut. Lokasi kajian yakni Pantai Munggangsari, Kecamatan Grabag, Kabupaten Purworejo, Provinsi Jawa Tengah. Metode yang digunakan dalam penelitian ini meliputi studi literatur, penginderaan jauh, survei lapangan (pengamatan dan pengukuran langsung), dan wawancara. Dari hasil analisis data dan citra terjadi peningkatan aktivitas peternakan dan perikanan tambak di wilayah Pesisir Purworejo dari tahun 2006 hingga 2014. Adanya aktivitas kegiatan tersebut berpotensi memberikan dampak negatif terhadap lingkungan sekitar salah satunya terhadap kualitas airtanah. Sedangkan untuk penggunaan lahan berupa tanah kosong dan gisik pada umumnya terjadi penurunan luasan. $\mathrm{Hal}$ tersebut menunjukkan dari tahun 2006 - 2016 terjadi tekanan penduduk yang tinggi. Dibutuhkan kebijakan, kapasitas teknis (pengadaan sistem peringatan dini) pada lembaga serta mekanisme penanganan darurat bencana yang kuat dalam pengaplikasiannya.
\end{abstract}

Kata Kunci: Purworejo, Wilayah Kepesisiran, Risiko bencana, Penginderaan Jauh, EWS 


\section{PENDAHULUAN}

Indonesia sebagai negara kepulauan (archipelagic state) dengan panjang garis pantai $99.093 \mathrm{~km}$ sekaligus juga sebagai negara yang memiliki garis pantai terpanjang kedua di dunia (Poerwadi, 2018). Kondisi tersebut memunculkan konsekuensi dari panjangnya garis pantai yang dimiliki negara ini berupa wilayah kepesisiran yang luas, karakteristik yang beragam dengan segala potensinya. Wilayah kepesisiran merupakan wilayah yang menyimpan limpahan potensi sumberdaya.

Adanya potensi sumberdaya pada wilayah kepesisiran akan mempengaruhi pola penggunaan lahan oleh masyarakat lokal dalam memenuhi kebutuhan hidupnya. Sebagaimana yang diuraikan oleh Lozi \& Rahmad (2019) dalam Solihuddin (2010) yakni kawasan pantai memiliki dinamika, yang dalam memiliki konsep bahwa ruang pantai baik dari aspek bentuk dan lokasinya dapat berubah dengan cepat sebagai bentuk reaksi terhadap proses alam dan aktivitas manusia (antropogenik).

Hal ini sejalan dengan yang dikemukakan oleh Anjulian dan Nurman (2017) bahwa seiring berjalannya perkembangan peradaban serta tingginya kebutuhan manusia, maka akan berimplikasi dengan perubahan penggunaan lahan. Secara umum penggunaan lahan di Indonesia merupakan wujud nyata yang timbul sebagai konsekuensi logis dari suatu proses yang lama karena adanya interaksi yang tetap (Sidauruk \& Simanungkalit, 2015). Namun, hal yang penting untuk disadari bahwa selain potensi sumberdaya yang terdapat di wilayah kepesisiran, wilayah tersebut juga memiliki potensi bahaya yang punya ruang lingkup tersendiri untuk dilakukan kajian mendalam.

Kabupaten Purworejo salah satu kabupaten di wilayah pesisir yang letaknya di pantai selatan Pulau Jawa (Damayanti dkk, 2019). Pesisir Kabupaten Purworejo memiliki wilayah pesisir yang karakteristik materialnya terdiri dari akumulasi sedimen bijih besi yang terangkut melalui Sungai Bogowonto yang bersumber dari Gunung Api Sumbing dan Gunung Api purba di Pegunungan Kubah Kulonprogo (D.I Yogyakarta), yang kemudian dimanfaatkan sebagai lahan pertambangan dengan potensi pasir besi. Aktivitas penambangan pasir besi di Kecamatan Grabag, Kabupaten Purworejo telah dilakukan mulai tahun 1987. Namun, kini tidak ada aktivitas penambangan (Rahmad, 2016).

Kajian tentang bahaya tsunami telah dirilis oleh BNPB dalam laporan Masterplan
Pengurangan Risiko Bencana Tsunami (2012) Kabupaten Purworejo merupakan salah satu dari empat belas kabupaten di wilayah Jawa Tengah, DI Yogyakarta, dan Jawa Timur yang apabila gempabumi pada skala besar terjadi, dengan hiposenter berada di Samudra Hindia di selatan Pulau Jawa, maka berpotensi terkena tsunami. Hal tersebut juga telah diperkuat dengan hasil kajian yang diuraikan pada Dokumen Kajian Risiko Bencana (KRB) Provinsi Jawa Tengah Tahun 2016-2020 (2015), Kabupaten Purworejo bila ditinjau dari aspek risiko bencana memiliki hasil yang beragam dalam hal ini berkaitan dengan hasil pengelompokkan kelas indeks kajian risiko bencana (kelas rendah, menengah, dan tinggi). Untuk bahaya banjir terkategori kelas tinggi, bahaya cuaca ekstrim terkategori kelas sedang, bahaya gempabumi terkategori kelas sedang, dan bahaya kekeringan masuk pada indeks kelas menengah. Sedangkan untuk bahaya gelombang ekstrim dan abrasi terkategori kelas tinggi. Selain itu, kabupaten ini masuk pada salah satu dari 5 kabupaten/ kota di provinsi Jawa Tengah yang memiliki indeks bahaya tsunami kelas tinggi.

Oleh sebab itu, dibutuhkan strategi pengelolaan untuk meminimalisir bahaya yang dapat terjadi sekaligus sebagai upaya pengembangan potensi yang ada. Pengelolaan yang dapat dilakukan di wilayah pesisir Purworejo dapat dilakukan dengan beberapa pendekatan salah satunya, pendekatan lingkungan. Pengelolaan yang dimaksud dalam konteks ini sejalah dengan dikemukakan oleh Masyhuri (2019) bahwa kegiatan alih fungsi lahan yang dilaksanakan tanpa melewati tahapan perencanaan dan pengendalian akan mengakibatkan kerusakan (degradasi) lingkungan

Dari hasil kajian yang diperoleh nantinya dapat digunakan sebagai acuan dalam perencanaan, pengelolaan, serta monitoring evaluasi guna pengembangan wilayah pesisir Purworejo. Penelitian ini bertujuan untuk mengkaji karakteristik fisik dan pola penggunaan lahan wilayah kepesisiran selatan Kabupaten Purworejo, Provinsi Jawa Tengah dalam hal pemanfaatan ruang pesisir secara eksisting dengan pendekatan lingkungan untuk kemudian menentukan strategi pengelolaan wilayah kepesisiran pada daerah tersebut.

\section{METODOLOGI}

Metode yang digunakan dalam mengkaji potensi, permasalahan pada lokasi kajian, 
dilakukan dengan studi literatur, penginderaan jauh, survei lapangan (survei terestris) yang meliputi pengamatan langsung (observasi) dan pengukuran langsung, serta wawancara. Sedangkan untuk perumusan strategi pengelolaan kawasan pesisir lokasi kajian berasal dari hasil analisis data lapangan yang ditampilkan secara deskriptif. Secara rinci metode yang digunakan dijabarkan sebagai berikut:

a. Studi Literatur: Studi literatur dilakukan pada tahap awal yaitu sebelum kegiatan lapangan. Studi literatur juga dilakukan pasca lapangan untuk memvalidasi hasil pengamatan dan pengukuran langsung di lapangan. Materi yang dikumpulkan terkait dengan karakteristik wilayah sebagian Purworejo baik sosial maupun fisik, serta karakteristik wilayah pesisir sebagian Purworejo. Studi literatur ini dilakukan untuk mendetailkan analisis berdasarkan hasil pengamatan dan pengukuran di lapangan.

b. Penginderaan Jauh: mencakup analisis fenomena fisik, sosial dan unsur geografis dengan pemanfaatan data penginderaan jauh seperti citra dan foto udara.

c. Pembuatan peta tentatif lokasi kajian: mencakup kegiatan interpretasi sebelum kegiatan lapangan dilakukan dengan metode penginderaan jauh, yaitu dengan memanfaatkan Citra Google Earth. Selain itu, juga dilakukan delineasi batas wilayah kepesisiran pada masing-masing lokasi kajian. Hasil peta tentatif ini kemudian dicocokkan dengan kondisi langsung di lapangan.

\section{HASIL PENELITIAN DAN PEMBAHASAN}

\section{Karakteristik Fisik di Wilayah Pesisir Purworejo}

Wilayah pesisir Pantai Munggangsari secara administratif berada di Kecamatan Grabag, Kabupaten Purworejo, Provinsi Jawa Tengah memiliki ciri topografi datar. Bila ditinjau dari aspek bentuklahan (landform), Kabupaten Purworejo memiliki empat jenis satuan bentuklahan asal proses diantaranya bentuklahan asal proses struktural, bentuklahan asal proses fluvial, bentuklahan asal proses marin dan bentuklahan asal proses denudasional (Rencana Kinerja Tahunan (RKT) Kabupaten Purworejo Tahun 2018). Dari hasil analisis aransemen bentuklahan, dari arah laut kearah darat meliputi dataran pantai, beting gisik dan dataran fluviomarin. Pemanfataan secara eksisting menunjukkan bahwa pada dataran pantai dibiarkan secara alami, sedangkan beting gisik dimanfaatkan sebagai tambak sedangkan dataran fluviomarin dimanfaatkan untuk pertanian lahan kering dan basah. Tipologi yang membentuk setiap wilayah pesisir mempunyai karakteristik tertentu, baik dari aspek penggunaan lahan dan tingkat perkembangannya. Hal ini tentunya berhubungan dengan potensi dan permasalahan setiap wilayah. Tipologi pesisir berpasir merupakan tipologi sebagian besar pesisir Purworejo.

\section{Pola Penggunaan Lahan di Wilayah Pesisir Purworejo}

Dalam Berdasarkan Peraturan Daerah Kabupaten Purworejo Nomor 27 Tahun 2011 tentang Rencana Tata Ruang Wilayah RTRW) Kabupaten Purworejo Tahun 2011-2031 bahwa Kecamatan Grabag merupakan salah satu dari tiga kecamatan yang termasuk kedalam Kawasan Strategis Kabupaten (KSK) dari sudut kepentingan pertumbuhan ekonomi yang terkategori sebagai Kawasan Bahari Terpadu (KBT) pada kawasan pesisir selatan Kabupaten seluas \pm 10.650 (sepuluh ribu enam ratus lima puluh) hektar, termasuk wilayah laut sejauh 4 (empat) mil dari garis pantai yang pengelolaannya menjadi kewenangan daerah. Selain itu, penggunaan lahan pada zonasi pesisir dapat diusahakan dengan kegiatan perikanan, tambak, industri, wisata dan lainnya dengan syarat tidak merusak kawasan fungsi lindung dan memperhatikan kesejahteraan masyarakat.

Pengembangan KBT tersebut diimplementasikan pada kegiatan budidaya air payau dan perikanan. Berdasarkan uraian pada Rencana Kinerja Tahunan (RKT) Kabupaten Purworejo Tahun 2018, diketahui bahwa Kabupaten Purworejo memiliki potensi air yang berasal dari air permukaan dan air bawah tanah. Di Kabupaten ini terdapat beberapa sungai yang mengalir di daerah ini dan bermuara di Samudera Indonesia. Sungai-sungai ini termasuk dalam Daerah Aliran Sungai (DAS) Bogowonto, Cokroyasan dan Wawar. Hulu hulu sungai tersebut umumnya berada di bagian timur dan utara Kabupaten Purworejo. Keberadaan sumberdaya air ini memiliki peranan penting dalam mendukung pengoperasionalan budidaya oleh masyarakat setempat.

Kegiatan budidaya air payau dikembangkan pada kegiatan tambak udang. Tambak udang dilakukan pada beting gisik dengan ciri material pasir. Permasalahan muncul ketika penggunaan lahan tidak memperhatikan aspek estetika lingkungan. Keberadaan tambak udang juga dapat menimbulkan masalah apabila 
pengelolaan limbah organik pada tambak udang tidak ditangani secara tepat.

Selain itu, penggunaan pupuk dan sisa limbah peternakan juga berpotensi pada pencemaran lingkungan. Pencemaran yang paling rentan terjadi adalah pencemaran terhadap airtanah. Arah aliran airtanah yang dominasi mengalir dari darat menuju wilayah pesisir/laut menyebabkan potensi pencemaran tertinggi berada di wilayah pesisir. Kondisi penggunaan lahan secara eksisting di lokasi kajian ditunjukkan pada Gambar 1.

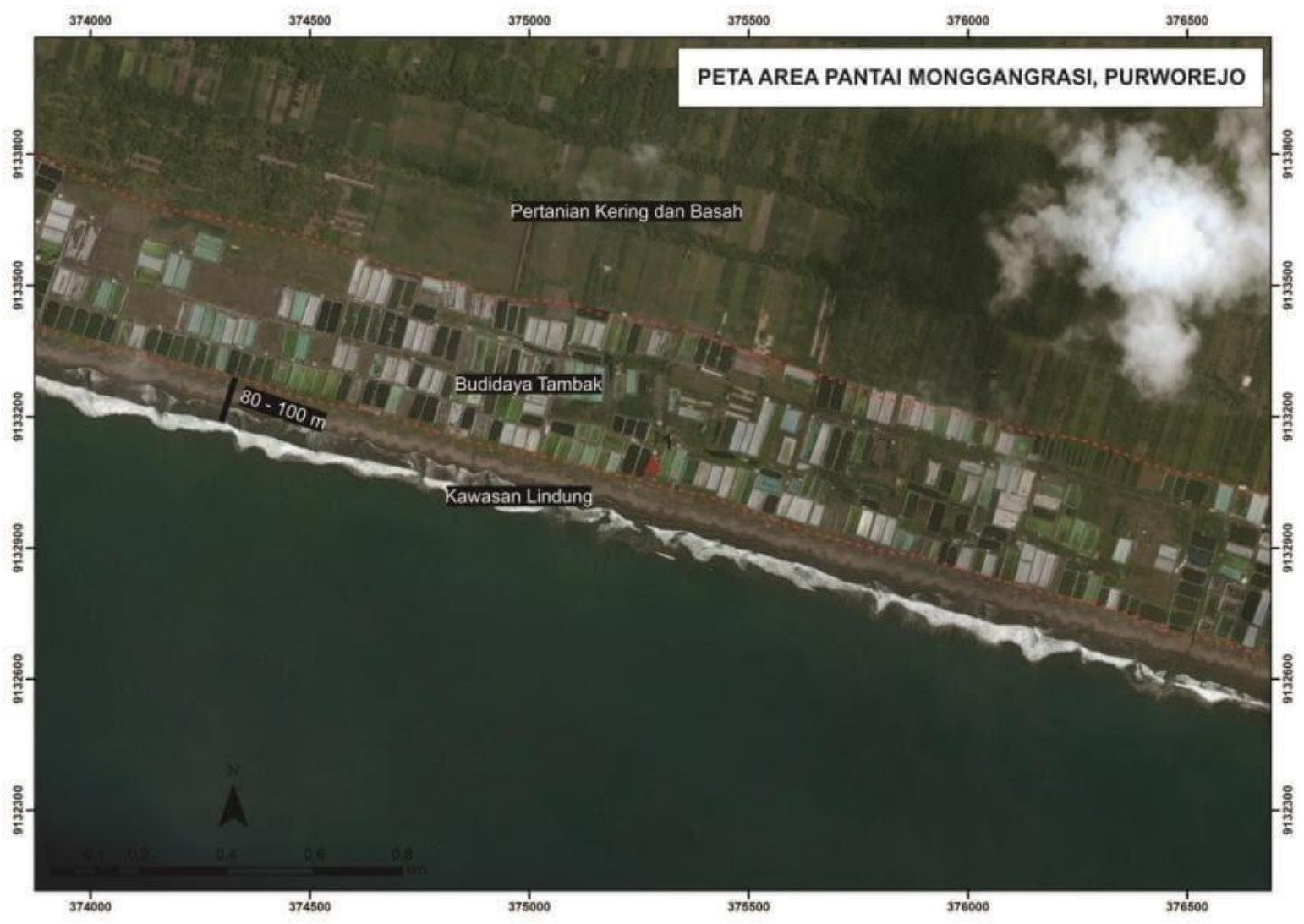

Gambar 1. Penggunaan Lahan di Wilayah Pesisir Pantai Munggangsari dan Sekitarnya

Berdasarkan hasil wawancara dengan masyarakat setempat diketahui bahwa budidaya ternak yang terdapat di Munggangsari atas kerjasama PT. ANTAM dengan Perusahaan UMI Perkasa. Biaya pembuatan kandang sapi maupun ayam ditanggung oleh PT. ANTAM. Keberadaan sejumlah kandang ayam serta sisa hasil kotoran ternak yang berada di tengah-tengah lahan pertanian cabai oleh masyarakat setempat dimanfaatkan sebagai pupuk organik, dengan rata-rata jumlah unit kelola yang dimiliki oleh masyarakat setempat mencapai maksimal 3 unit kandang ayam pedaging Gambar 2a, dengan kapasitas tampung per unit sebanyak 2500 hingga 3000 dengan total sebanyak 8000 bibit.

Harga bibit ayam yaitu Rp. 6.000/ekor, dengan resiko kematian ayam berkisar 200 ekor per unit tiap kandang. Harga jual ayam pedaging ini senilai $16.750 / \mathrm{kg}$. luran bulanan tambak dan peternakan ayam yaitu Rp 100.000. Estimasi laba ternak ayam yaitu Rp 2.000/ekor. Kotoran ayam selain digunakan sebagai pupuk di sekitar kandang ayam juga dijual seharga Rp. $40.000 / \mathrm{kol}$. Namun dari hasil wawancara juga diketahui bahwa, masyarakat setempat menyatakan bahwa penghasilan ternak ayam terbilang lebih kecil dibandingkan dengan tambak yang sangat potensial pada lokasi tersebut. Peternakan sapi juga merupakan program pengembangan di wilayah ini, terlihat melalui sarana berupa kandang yang baru didirikan, seperti yang ditunjukkan pada Gambar 2b.

Selain kegiatan observasi terhadap aktivitas pemanfataan lahan secara eksisting juga dilakukan identifikasi terhadap kondisi airtanah (groundwater) pada lokasi kajian. Pengujian air dilakukan pada air sumur dengan Tinggi Muka Air (TMA) 7-meter dengan menggunakan water checker (Gambar 3), untuk mengetahui beberapa parameter kondisi airtanah. Hasil pengukuran kualitas air ditunjukkan pada Tabel 1. Salah satu aktivitas dalam budidaya yang dilakukan untuk meningkatkan produktivitas 
pertanian dengan pemberian pupuk anorganik, misalnya NPK dan $\mathrm{KCl}$ serta pemberian pestisida dalam usaha menanggulangi serangan hama. Namun, kegiatan tersebut berpotensi memberikan dampak negatif terhadap lingkungan sekitar salah satunya terhadap kualitas air.

Apabila pupuk dan pestisida yang diberikan yang terakumulasi di dalam airtanah akan berbahaya bila digunakan sebagai air minum bagi manusia, konsumsi pakan ternak, serta bagi pengairan tambak. Berdasarkan citra temporal pada wilayah ini menunjukkan perkembangan yang signifikan sejak tahun 2006, hal tersebut mengindikasikan ketersediaan SDA yang melimpah di Munggangsari.

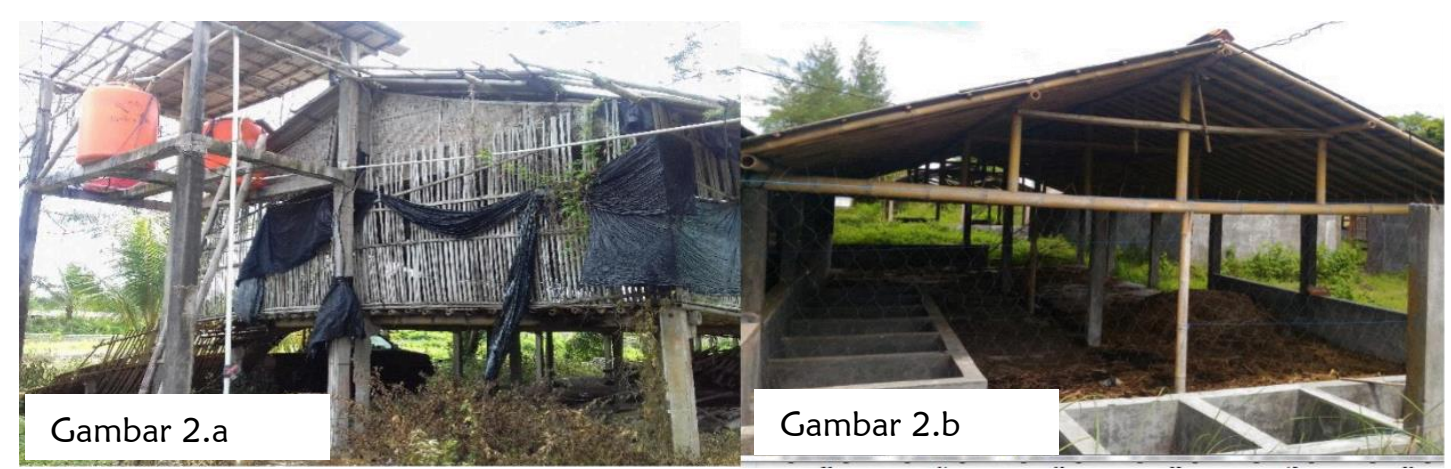

Gambar 2. a) Peternakan Ayam yang Dikelola oleh Masyarakat; b) Kandang Sapi yang Dikelola oleh Masyarakat (Sumber: Kegiatan Lapangan, 2017)

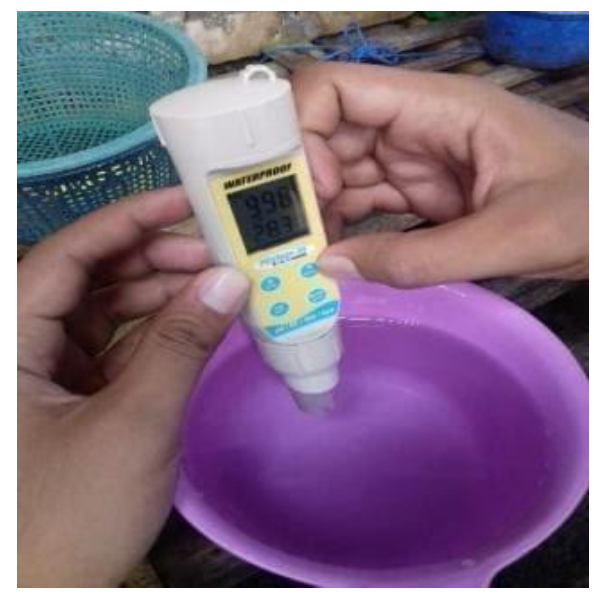

Gambar 3. Pengukuran Kondisi Airtanah (Sumber: Kegiatan Lapangan, 2017)

Tabel 1. Data Hasil Pengamatan Kondisi Airtanah

\begin{tabular}{lc}
\hline \multicolumn{1}{c}{ Parameter } & Keterangan \\
\hline Salinitas & $617 \mathrm{ppm}$ \\
$\mathrm{pH}$ & 7,5 (Basa) \\
$\mathrm{DHL}$ & $1002 \mu \mathrm{mhos} / \mathrm{cm}$ (Payau) \\
$\mathrm{TDS}$ & $713 \mathrm{mg} / \mathrm{liter}$ \\
Temperatur & $28.3^{\circ} \mathrm{C}$ \\
\hline (Sumber: Kegiatan Lapangan, 2017 )
\end{tabular}

Pemanfaatan wilayah kepesisiran ini salah satunya dikembangkan melalui sektor peternakan yang merupakan bekas tambang pasir, perkembangan penggunaan lahan secara 
spasial (2006-2016) ditunjukkan pada Gambar 4, 5, dan 6. Berdasarkan hasil analisis data pengelolaan pesisir sector peternakan di wilayah pesisir Purworejo, perkembangan lahan tambak menunjukkan hasil signifikan, seperti yang ditunjukkan pada Tabel 2 dan Tabel 3. Hasil tersebut menunjukkan adanya penggunaan lahan tambak meningkat dalam kurun waktu
2014-2016. Sumberdaya lahan pada wilayah beting gisik yang berada dekat dengan laut dan sumberdaya airtanah dangkal membuat budidaya perikanan payau dapat dikembangkan dengan baik. Persentasi perubahan lahan pada kurun waktu 2014-2016 ditunjukkan pada Tabel 4 dan Tabel 5.

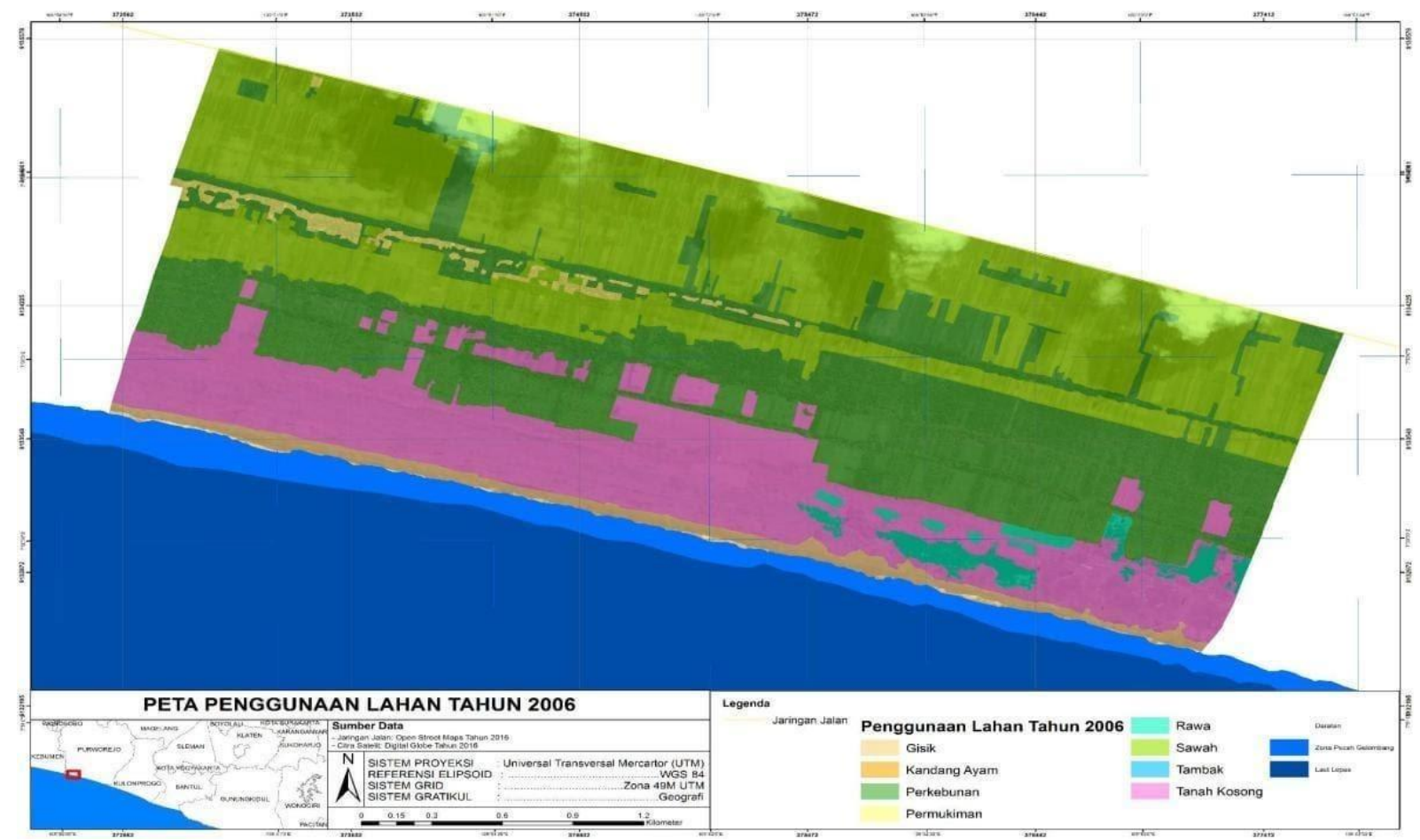

Gambar 4. Peta Penggunaan Lahan Lokasi Kajian Tahun 2006 


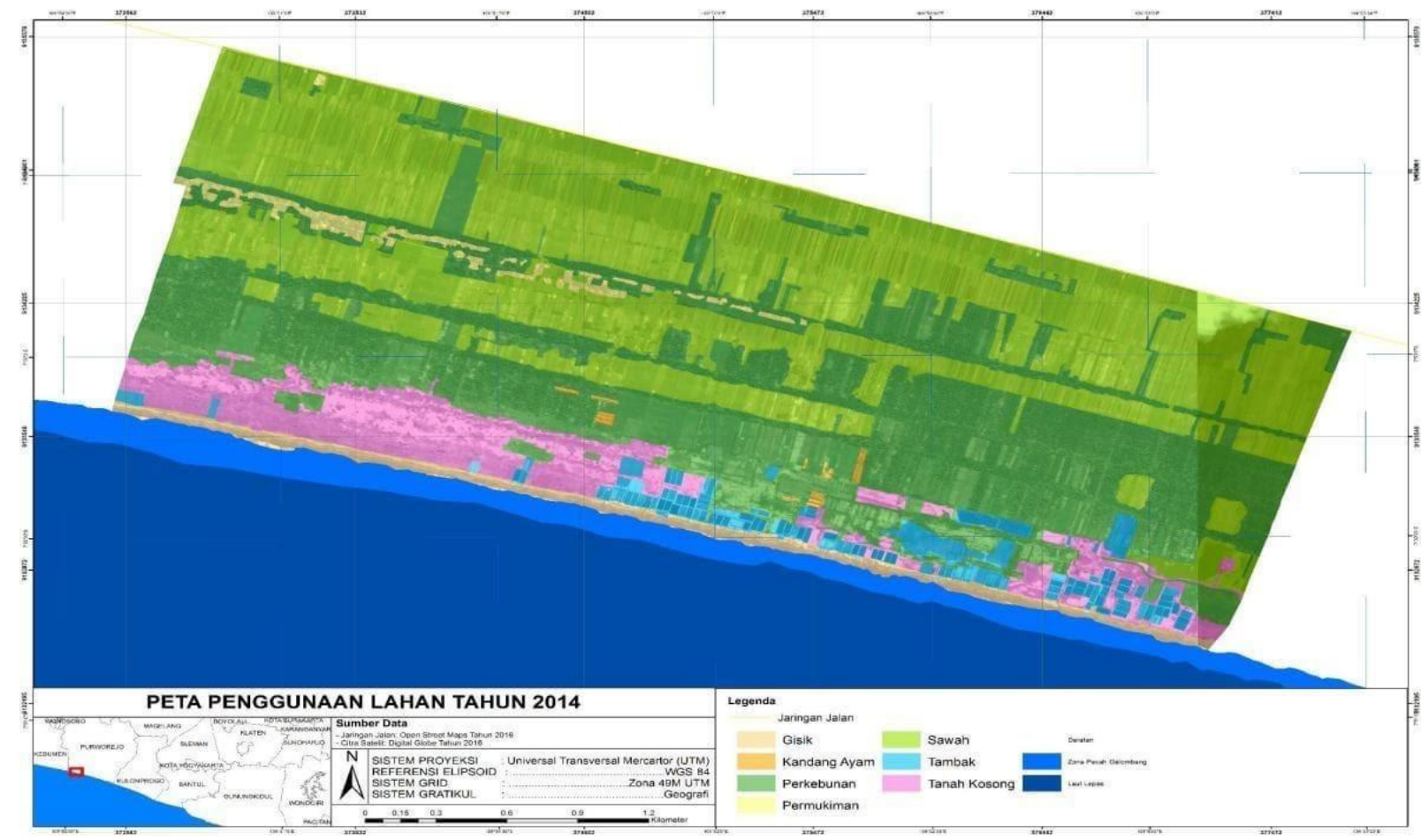

Gambar 5. Peta Penggunaan Lahan pada Lokasi Kajian Tahun 2014

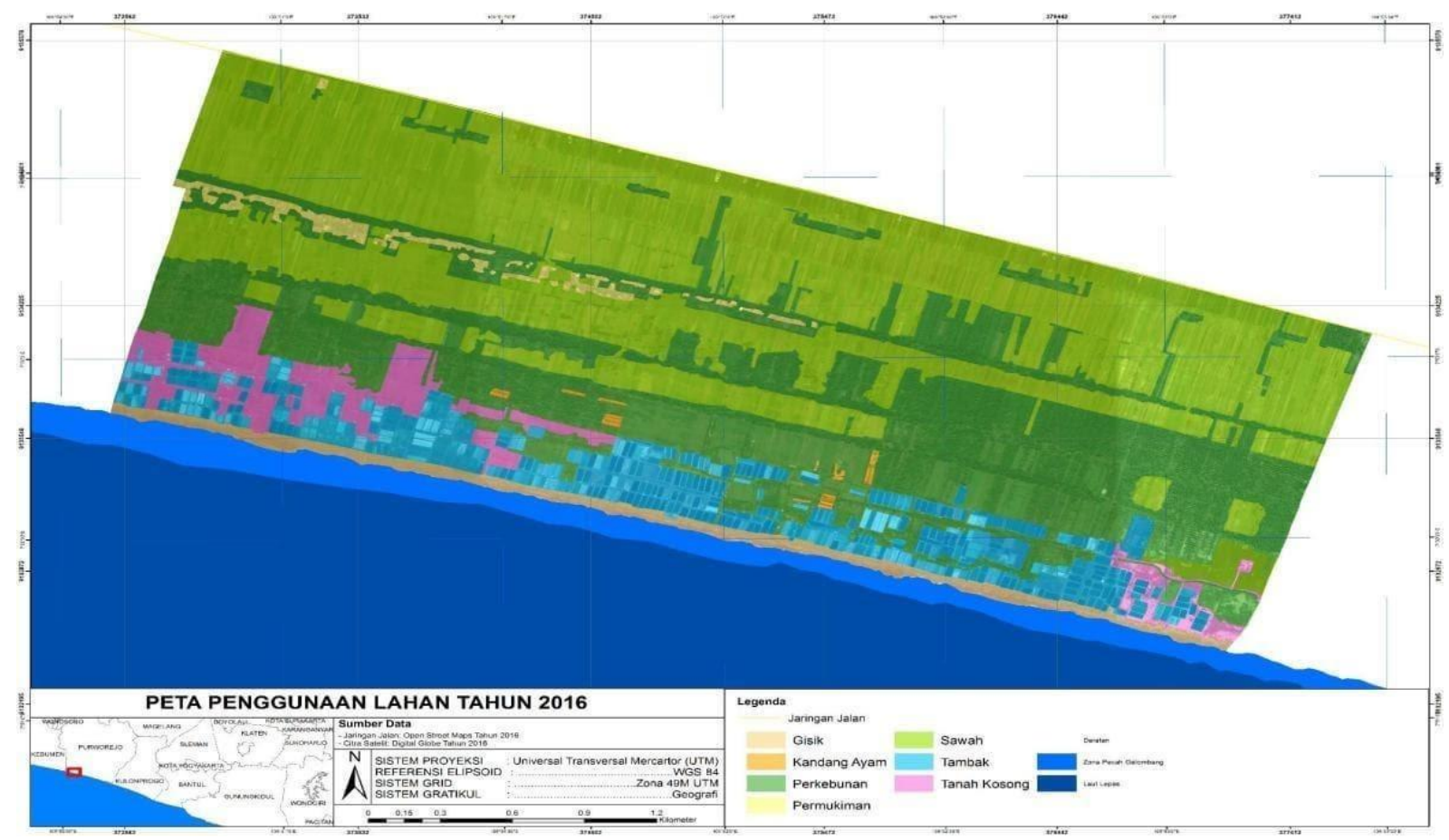

Gambar 6. Peta Penggunaan Lahan pada Lokasi Kajian Tahun 2016

Tabel 2. Hasil analisis data perubahan penggunaan lahan tahun 2006 ke 2014

\begin{tabular}{|c|c|c|c|c|c|c|c|c|c|}
\hline & & \multicolumn{7}{|c|}{ Penggunaan Lahan Tahun 2014} & \multirow{2}{*}{$\begin{array}{l}\text { Total } \\
(\mathrm{Ha})\end{array}$} \\
\hline & & Gisik & Peternakan & Perkebunan & Permukiman & Sawah & Tambak & $\begin{array}{l}\text { Tanah } \\
\text { Kosong }\end{array}$ & \\
\hline \multirow{4}{*}{$\begin{array}{l}\text { Penggunaan } \\
\text { Lahan } \\
\text { Tahun } 2006\end{array}$} & Gisik & 26,84 & 0,00 & 0,03 & 0,00 & 0,00 & 1,55 & 2,08 & 30,50 \\
\hline & Perkebunan & 0,00 & 1,31 & 263,82 & 0,00 & 27,43 & 0,00 & 0,00 & 292,56 \\
\hline & Permukiman & 0,00 & 0,00 & 0,00 & 11,64 & 0,00 & 0,00 & 0,00 & 11,64 \\
\hline & Rawa & 0,00 & 0,11 & 5,23 & 0,00 & 3,21 & 6,35 & 2,34 & 17,24 \\
\hline
\end{tabular}




\begin{tabular}{ccccccccc}
\hline $\begin{array}{c}\text { Sawah } \\
\text { Tanah } \\
\text { Kosong }\end{array}$ & 0,00 & 0,00 & 0,00 & 0,00 & 340,79 & 0,00 & 0,00 & 340,79 \\
\hline Total (HA) & 27,01 & 0,68 & 73,69 & 0,00 & 18,89 & 25,84 & 75,73 & 195,00 \\
\hline
\end{tabular}

(Sumber: Hasil analisis data, 2017)

Tabel 3. Hasil analisis data perubahan penggunaan lahan tahun 20014 ke 2016

\begin{tabular}{|c|c|c|c|c|c|c|c|c|c|}
\hline & & \multicolumn{7}{|c|}{ Penggunaan Lahan Tahun 2016} & \multirow{2}{*}{$\begin{array}{l}\text { Total } \\
(\mathrm{HA})\end{array}$} \\
\hline & & Gisik & Peternakan & Perkebunan & Permukiman & Sawah & Tambak & $\begin{array}{l}\text { Tanah } \\
\text { Kosong }\end{array}$ & \\
\hline \multirow{7}{*}{$\begin{array}{c}\text { Penggunaan } \\
\text { Lahan Tahun } \\
2014\end{array}$} & Gisik & 27,5 & 0 & 0 & 0 & 0 & 0 & 0 & 27,5 \\
\hline & Peternakan & 0 & 2,1 & 0 & 0 & 0 & 0 & 0 & 2,1 \\
\hline & Perkebunan & 0 & 0,28 & 299,77 & 0 & 9,22 & 13,84 & 19,66 & 342,77 \\
\hline & Permukiman & 0 & 0 & 0 & 11,64 & 0 & 0 & 0 & 11,64 \\
\hline & Sawah & 0 & 0 & 0 & 0 & 390,32 & 0 & 0 & 390,32 \\
\hline & Tambak & 0 & 0 & 0,62 & 0 & 0 & 33,12 & 0 & 33,74 \\
\hline & $\begin{array}{l}\text { Tanah } \\
\text { Kosong }\end{array}$ & 0 & 0 & 4,53 & 0 & 0 & 51,93 & 23,68 & 80,14 \\
\hline \multicolumn{2}{|c|}{ Total $(\mathrm{HA})$} & 27,5 & 2,38 & 304,92 & 11,64 & 399,54 & 98,89 & 43,34 & 888,21 \\
\hline
\end{tabular}

(Sumber: Hasil analisis data, 2017)

Tabel 4. Hasil analisis data persentase perubahan penggunaan lahan tahun 2006 ke 2014 (\%)

\begin{tabular}{|c|c|c|c|c|}
\hline \multirow{2}{*}{ Penggunaan Lahan } & \multirow{2}{*}{ Luas Tahun $2006(\mathrm{Ha})$} & \multirow{2}{*}{ Luas Tahun $2014(\mathrm{Ha})$} & \multicolumn{2}{|c|}{ Pertumbuhan 2006-2014 } \\
\hline & & & $(\mathrm{Ha})$ & (\%) \\
\hline Gisik & 30,50 & 27,50 & $-3,00$ & $-9,84$ \\
\hline Rawa & 17,23 & 0,00 & $-17,23$ & $-100,00$ \\
\hline Permukiman & 11,64 & 11,64 & 0,00 & 0,00 \\
\hline Perkebunan & 292,56 & 342,77 & 50,21 & 17,16 \\
\hline Persawahan & 340,79 & 390,32 & 49,53 & 14,53 \\
\hline Peternakan & 0,00 & 2,10 & 2,10 & 100,00 \\
\hline Perikanan Tambak & 0,00 & 33,74 & 33,74 & 100,00 \\
\hline Tanah Kosong & 195,00 & 80,14 & $-114,86$ & 59,90 \\
\hline
\end{tabular}

(Sumber: Hasil analisis data, 2017)

Tabel $\underline{5 .}$ Hasil analisis data persentase perubahan penggunaan lahan tahun 2014 ke 2016 (\%)

\begin{tabular}{lrrrr}
\multirow{2}{*}{ Penggunaan Lahan } & Luas Tahun $2014(\mathrm{Ha})$ & Luas Tahun $2016(\mathrm{Ha})$ & \multicolumn{2}{c}{ Pertumbuhan 2014-2016 } \\
\cline { 4 - 5 } & & & \multicolumn{1}{c}{$(\mathrm{Ha})$} & \multicolumn{1}{c}{$(\%)$} \\
\hline Gisik & 27,50 & 27,01 & $-0,49$ & $-1,78$ \\
Rawa & 0,00 & 0 & 0,00 & 0 \\
Permukiman & 11,64 & 11,64 & 0,00 & 0 \\
Perkebunan & 342,77 & 304,92 & $-37,85$ & $-11,04$ \\
Persawahan & 390,32 & 399,53 & 9,21 & 2,36 \\
Peternakan & 2,10 & 2,38 & 0,28 & 13,33 \\
Perikanan Tambak & 33,74 & 98,89 & 65,15 & 193,09 \\
Tanah Kosong & 80,14 & 43,34 & $-36,80$ & $-45,92$ \\
\hline (Sumber: Hasil analisis data, 2017) & & &
\end{tabular}

Hasil menunjukkan persentasi terbesar penambahan ciri penggunaan lahan adalah pada kegiatan budidaya seperti tambak, pertanian, dan peternakan. Ciri penggunaan lahan tanah kosong dan gisik pada umumnya terjadi penurunan luasan. Hal tersebut menunjukkan 
dari tahun 2006 - 2016 terjadi tekanan penduduk yang tinggi. Aktivitas peternakan di wilayah Pesisir Purworejo dari tahun ke tahun juga mengalami peningkatan pada tahun dari tahun 2006 hingga 2014, luas lahan yang digunakan untuk pengembangan sektor peternakan meningkat $2,10 \mathrm{Ha}$, lalu pada tahun 2016 mengalami peningkatan lagi sebesar 0,28 Ha. Peningkatan luas lahan pada sektor peternakan juga ditandai dengan peningkatan jumlah kandang ternak yang saat tahun 2014 mencapai 19 kandang bertambah jumlahnya menjadi 21 kandang.

Berdasarkan analisis data hasil pengamatan lapangan, diestimasikan bahwa peningkatan jumlah luasan lahan peternakan serta jumlah kendang berimplikasi pada peningkatan hasil produksi per masa panen (ekor), seperti yang dilampirkan pada Tabel 6 dan Gambar 7 . Fenomena perubahan penggunaan lahan pada sejumlah kota di Indonesia didasari oleh faktor pendorong yang berbeda, misal pada Kota
Batam yang secara dominan didorong oleh kebijakan pemerintah daerah, kemudian perubahan penggunaan lahan pada Kota Malang didominasi oleh fenomena urban sprawl, sedangkan pada Kota Pemalang dalam perubahan lahan pada kota tersebut didominasi oleh tumbuhnya pusat-pusat hirarkhi wilayah baru. Namun, lain halnya yang terjadi di Muara Jambi, yang secara umum perubahan penggunaan lahan disebabkan oleh kebutuhan lahan untuk menunjang aktivitas pertanian (Pribadi, Shiddiq, \& Ermyanila, 2006).

Dari aspek perubahan penggunaan lahan, kawasan pesisir Kota Kupang dalam kajian yang dilakukan oleh Siubelan, Murtilaksono, \& Lubis (2015) memiliki dinamika perubahan dalam rentang waktu 1999-2013, dengan penggunaan lahan paling sigfinkan dari segi luasannya adalah permukiman tetapi justru beberapa jenis penggunaan lahan yang mengalami degradasi yakni, lading/ tegalan/ belukar, hutan bakau, serta sawah.

Tabel 6. Perkembangan aktivitas peternakan di wilayah pesisir Purworejo

\begin{tabular}{lccc}
\hline \multicolumn{1}{c}{ Komponen } & 2006 & $\mathbf{2 0 1 4}$ & $\mathbf{2 0 1 6}$ \\
\hline Luas Lahan (Ha) & 0 & 2.10 & 2.38 \\
Jumlah Kandang & 0 & 19 & 21 \\
Estimasi Produksi/ Masa Panen (ekor) & 0 & 87500 & 99166 \\
\hline
\end{tabular}

(Sumber: Hasil analisis data, 2017)

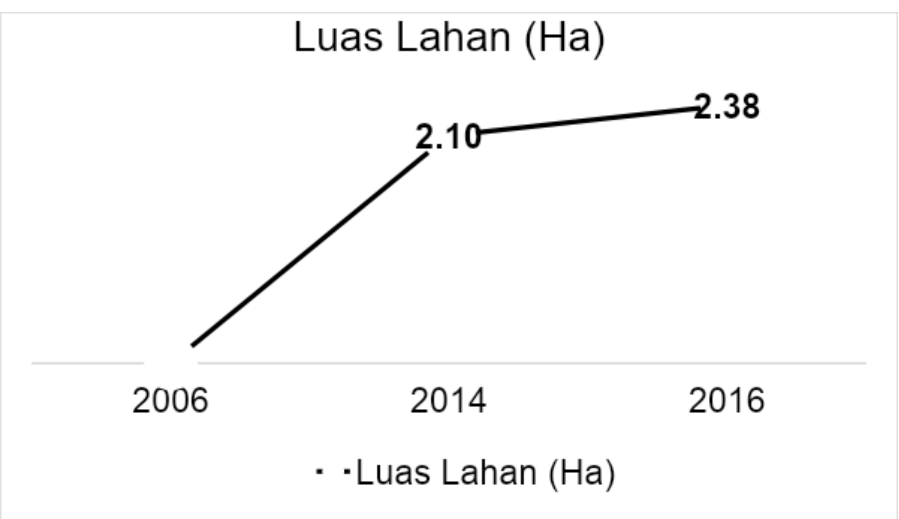

Gambar 7. Grafik Perkembangan Luas aktivitas peternakan di wilayah pesisir Purworejo (2006-2016)

(Sumber: Hasil analisis data, 2017)

\section{Strategi Pengelolaan di Wilayah Pesisir Purworejo}

Pengelolaan yang dapat dilakukan di wilayah pesisir Purworejo khususnya pada Pantai Munggangsari dapat dilakukan dengan pendekatan lingkungan. Pengelolaan yang dilakukan pertama adalah pemenuhan semua fasilitas guna mengingkatkan potensi di pesisir Purworejo. Pendekatan pengelolaan juga didasarkan pada potensi bahaya. Potensi bahaya gempa dan tsunami di lokasi kajian mengharuskan adanya pembuatan jalur evakuasi 
dan pemasangan Sistem Peringatan Dini (Early Warning System). EWS merupakan hal penting sebagai upaya mitigasi terhadap bahaya gelombang ekstrim, abrasi dan tsunami. EWS bertujuan untuk meminimalsir dampak yang timbul dari bahaya yang ada di wilayah kepesisiran. Pada penerapan lebih lanjut, adanya EWS akan memudahkan masyarakat yang berada di wilayah pesisir untuk menyelamatkan diri apabila terjadi bencana. Kondisi eksisting di wilayah pesisir selatan Purworejo belum memiliki adanya EWS maupun posko tim SAR di sekitar wilayah pesisir ini. Hal tersebut sangat berisiko mengingat adanya potensi yang dapat terjadi di wilayah kepesisiran yang telah dijabarkan pada bagian sebelumnya.

Jarak antara aktivitas manusia dengan pantai harus sesuai dengan sempadan pantai. Adanya koordinasi antara pemerintah juga perlu dilakukan sehingga semua potensi yang ada dapat dikembangkan. Melibatkan unsur masyarakat dalam setiap pengambilan keputusan sehingga tidak akan ada lagi permasalahan sosial yang terjadi. Sosialisasi dan pelatihan dapat dilakukan kepada masyarakat

Permasalahan yang muncul akibat adanya tambak di Pantai Monggangsari yaitu berpotensi terhadap pencemaran air tanah karena limbah tambak, pencemaran air lindi/ leachate, intrusi air laut, dan berada pada wilayah bahaya gelombang ekstrim, abrasi dan tsunami.

\section{UCAPAN TERIMA KASIH}

Terima kasih kepada Tuhan Yang Maha Esa karena atas izin-Nya sehingga penelitian dan artikel ini dapat terselesaikan, serta kepada seluruh pihak yang telah berkontribusi dalam penelitian ini.

\section{DAFTAR PUSTAKA}

Anjulian, L. dan Nurman, A. (2017). Analisis Perubahan Penggunaan Lahan di Kecamatan Pekanbaru Kota Tahun 2007 Dan Tahun 2014. Tunas Geografi Vol. 6 No. 22017 (174-187).

Badan Nasional Penanggulangan Bencana. (2012). Masterplan Pengurangan Risiko Bencana Tsunami. Badan Nasional Penanggulangan Bencana (BNPB).

Damayanti, A.P, Hardiana, A., \& Rahayu, P. (2019). Faktor-Faktor yang Mempengaruhi Perkembangan Permukiman di Wilayah Pesisir Kabupaten Purworejo. Region: Jurnal Pembangunan Wilayah dan Perencanaan Partisipatif, 14(2), 154-172. sekitar wilayah pesisir untuk meningkatkan kapasaitas masyarakat di sekitar wilayah pesisir.

\section{KESIMPULAN}

Penggunaan lahan pada wilayah kepesisiran dapat maksimal apabila dikelola secara tepat. Dalam hal ini pengelolaan yang dimaksud yakni pengelolaan yang tidak hanya berbasis potensi sumberdaya tapi juga potensi bahaya yang didasari oleh kajian ilmiah. Pengolaan tersebut harus didukung dengan adanya kebijakan, kapasitas teknis pada lembaga serta mekanisme penanganan darurat bencana yang kuat dengan perspektif pengurangan risiko bencana dalam aktualisasinya.

Pemanfaatan Pantai Monggangsari sebagai aktivitas peternakan dan perikanan tambak tidak sesuai karena batas pengelolaan sumberdaya sempadan pantai adalah $100 \mathrm{~m}$ dari pasang tertinggi. Selain itu, pada lokasi ini tidak terdapat bangunan fisik pelindung pantai, yang ada hanya bangunan fisik pendukung semi permenen untuk mendukung aktivitas perekonomian.

Deputi Bidang Pencegahan dan Kesiapsiagaan. Dokumen Kajian Risiko Bencana (KRB) Provinsi Jawa Tengah Tahun 2016-2020. (2015). Badan Nasional Penanggulangan Bencana.

Lozi, A., \& Rahmad, R. (2019). Analisis Perubahan Garis Pantai Menggunakan Data Penginderaan Jauh Di Pantai Cermin, Kabupaten Serdang Bedagai. Tunas Geografi, $7(1), \quad 69$. https://doi.org/10.24114/tgeo.v7i1.12230.

Masyhuri, W. (2019). Analisa Perubahan Penggunaan Lahan Terhadap Potensi Banjir Di Kecamatan Medan Denai. Tunas $\begin{array}{lll}\text { Geografi, } & 7 & (2),\end{array}$ https://doi.org/10.24114/tgeo.v7i1.7192.

Peraturan Bupati Kabupaten Purworejo. (2010). Rencana Tata Ruang Wilayah (RTRW) Kabupaten Purworejo Tahun 2011-2031. Peraturan Daerah Nomor: 27 Tahun 2011. Bupati Purworejo. Purworejo.

Poerwadi, B.S. (2018). Refleksi 2017 dan Outlook 2018 Membangun dan Menjaga Ekosistem Laut Indonesia Bersama Ditjen Pengelolaan Ruang Laut (Siaran Pers). Kementerian Kelautan dan Perikanan.

Pribadi, D. O., Shiddiq, D., \& Ermyanila, M. (2006). Model Perubahan Tutupan Lahan dan Faktor-Faktor yang Mempengaruhinya. Jurnal Teknik 
Lingkungan, 7(1), 35-51.

Rahmad, R. (2016). Identifikasi Permasalahan dan Rekomendasi Strategi Pengelolaan Pesisir Purworejo-Jawa Tengah (Studi Kasus: Areal Bekas Penambangan PT Antam). Jurnal Geografi, 8(1).

Sidauruk, E., \& Simanungkalit, N. M. (2015). Analisis Bentuk Penggunaan Lahan di Kecamatan Raya Kabupaten Simalungan Tahun 2001 Dan 2011. Jurnal Tunas Geografi, 4(1), 9-16.

Siubelan, Y. C. W., Murtilaksono, K., \& Lubis, D. P. (2015). Dinamika Keruangan Pesisir Kota Kupang Provinsi Nusa Tenggara Timur. Pengelolaan Sumberdaya Alam Dan Lingkungan, 5(1), 71-78. 
